Our Nature (2013), 11(1): 76-84

\title{
Fish Diversity and Conservation Perspectives of Gandak River, India
}

\author{
P.K. Srivastava \\ Central Inland Fisheries Research Institute (ICAR), Barrackpore, Kolkata - 700120, India \\ E-mail: pksrivastava17@yahoo.co.in
}

Received: 12.02.2012, Accepted: 08.05.2013

\begin{abstract}
Study of $10 \mathrm{~km}$ stretch of Gandak River in Uttar Pradesh revealed the ichthyofaunal diversity, assemblage structure, distribution pattern, threat status, ornamental and commercially important fishes. In all 54 fish species were recorded of many commercially important fishes. Among these species $45 \%$ belong to lower risk near threatened (LRnt), 26\% vulnerable (VU), 11\% lower risk least concern (LRlc), 11\% not evaluated (NE) and 7\% endangered (EN) category. Cyprinidae 33\% were most important followed by Bagridae (11\%), Channidae (9\%), Tetradontidae (5\%).
\end{abstract}

Key words: Fish diversity, Endangered species, Conservation status, Gandak River

\section{Introduction}

Gandak River is one of the major tributaries of Ganges fed by perpetual snow of the Himalayas. It harbors rich diversed fauna of many commercially important fishes. It is also known as Gandaki and Narayani River. The river travers about $300 \mathrm{~km}$ and flow through Bihar. The catchment area of the river is $7620 \mathrm{~km}^{2}$ in the Gangetic plain of Uttar Pradesh (only small area of river) and Bihar states and joins the Ganges near Hajipur in Bihar.

In India 2500 fish species have been reported, of which $930(40 \%)$ are freshwater inhabitant (Bhat, 2000). David (1963) conducted intensive survey of upper stretch $(185 \mathrm{~km})$ of the Gandak River between 161 $\mathrm{km}$ above and $24 \mathrm{~km}$ below the Bhaisalotan barrage. This survey is considered as the pioneer work. A fisheries survey of upper head water of Gandak river was conducted by David (1963). Many workers worked on fish species richness of the different aquatic systems in India but only a few reports are from the Gandak River system. Menon
(1974) has listed 141 species, belonging to 72 genera, 30 families and 11 orders from Ganga River system. However, in view of non-availability of records on fish diversity in Gandak River between Chhitauni Bagaha Rail Bridge to Chhitauni Ghat of Uttar Pradesh, the present study was undertaken for the first time to examine the fish diversity of Gandak River system in Eastern Uttar Pradesh.

India is one of the mega biodiversity hotspots in the world and occupies the ninth position in terms of freshwater mega biodiversity (Mittermeier et al., 1997). Biodiversity conservation is one of the major issues throughout the world and aquatic environments are serious threats to both diversity and ecosystem stability and therefore, it is necessary to protect and develop research and systematic conservation planning to protect freshwater biodiversity (Lakra et al., 2010). Various methods and strategies have been proposed by many workers (Cowx, 1998; Lakra et al., 2006). 


\section{P.K. Srivastava / Our Nature (2013) 11(1): 76-84}

In present study, ichthyofaunal diversity of Gandak River has been documented. The conservation status of the fishes has also been evaluated.

\section{Materials and methods \\ Study area and sampling sites}

The Gandak River, a key tributary of the Ganga River system in eastern India has been selected for this study. It is endowed with rich aquatic biodiversity of flora and fauna. The study was conducted to achieve the objective covering a $10 \mathrm{~km}$ stretch from Chhitauni Bagaha Rail Bridge $27^{\circ} 8^{\prime} 25.53^{\prime \prime} \mathrm{N}$ and $83^{\circ} 59^{\prime} 21.49^{\prime \prime} \mathrm{E}$ (about $3 \mathrm{~km}$ away from the Valmiki National Park and Tiger Reserve to Chhitauni Ghat $27^{\circ} 5^{\prime} 29.33^{\prime \prime} \mathrm{N}$ and $84^{\circ} 0^{\prime} 13.06^{\prime \prime} \mathrm{E}$ of Gandak River at an elevation of $81 \mathrm{~m} \mathrm{msl}$.

\section{Data collection}

Field surveys were conducted during November 2010 to October 2011. Fish samples were collected from two sites within $10 \mathrm{~km}$ river stretch of Gandak River viz., Site 1- Chhitauni Bagaha Rail Bridge and Site 2- Chhitauni Ghat (Fig. 1).

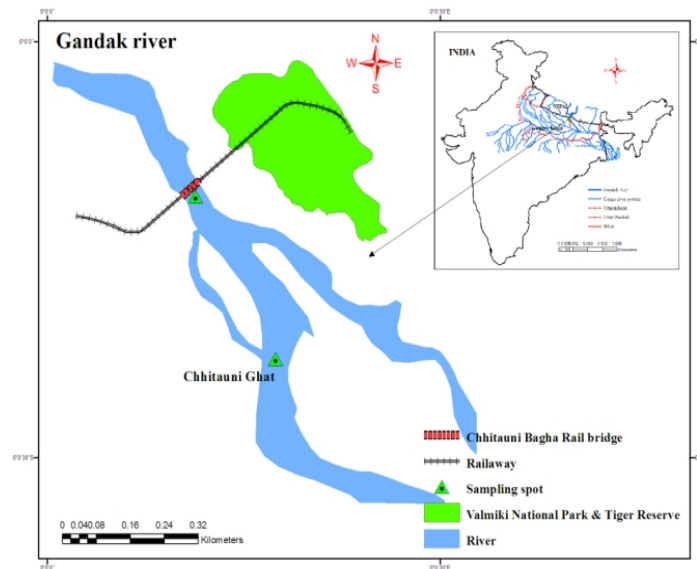

Figure 1. Gandak River showing sampling sites.
Fish collection was made with the help of local fisherman and the catches of fishers. The fishing was done by using different mesh size gill net, cast net, trap and angling. After the collection of fish, the sampled specimens were immediately preserved in $10 \%$ formalin for identifycation. Before preservation photograph was taken with the help of Nikon digital camera. The identification was made with the help of taxonomic references (Jhingran, 1975; Linderberg, 1976; Day, 1978; Srivastava, 1986; Talwar and Jhingran, 1991; Jayaram, 1999; Das et al., 2010). The conservation status of fishes based on conservation assessment and management plan for freshwater fishes of India (Molur and Walker, 1998).

\section{Results and discussion}

Comprehensive records on the fisheries of river Gandak are scanty. River is the major source of fisheries and contributes significantly to the inland capture fish production. But during last few decades the riverine system witnessed clear alterations due to enormous human interventions in the form of water abstraction, dam construction, sedimentation and illogical fishing. These have discerningly adverse effect on natural fish production, which showed constant declining trends.

The evaluation of conservation status of the fishes and the results of the present study revealed that $45 \%$ of the fishes belong to lower risk near threatened (LRnt), 26\% vulnerable (VU), 11\% lower risk least concern (LRlc), 11\% not evaluated (NE), and $7 \%$ endangered (EN) category (Fig. 2).

In the present study in all 54 fish species were recorded belonging to 18 


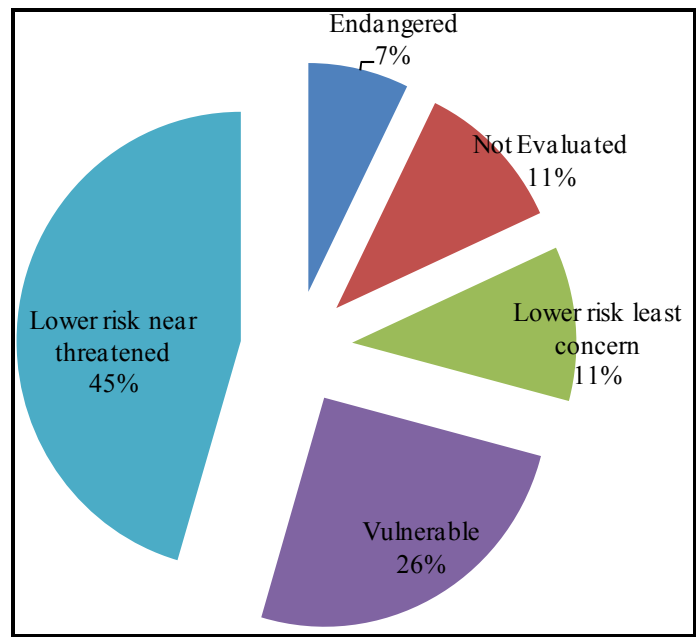

Figure 2. Conservation status of fish fauna of Gandak River.

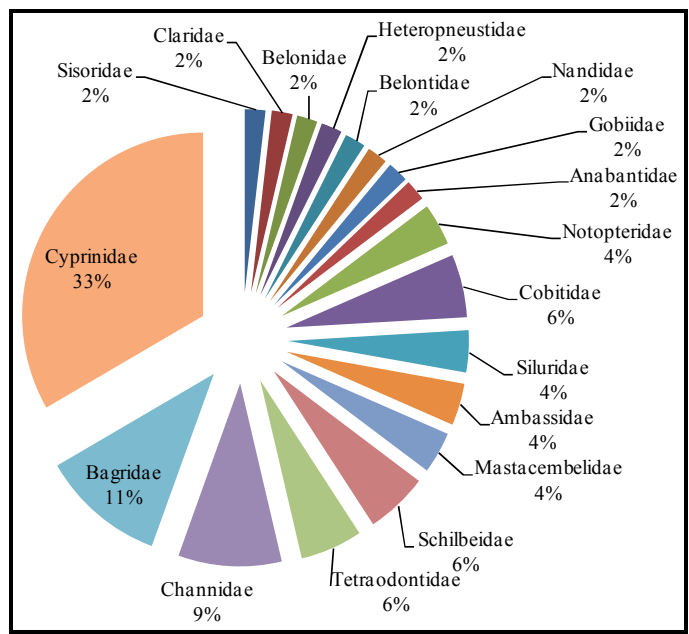

Figure 3. Family-wise percentage composition of fishes of Gandak River.

families from $10 \mathrm{~km}$ stretch of river Gandak. Taxonomic position, vernacular name, conservation status and spot of collection of the individual fish species assorted according to family are listed in table 1. Previously, David (1963) listed 113 fish species in the Gandak River at upper stretch, $161 \mathrm{~km}$ above and $24 \mathrm{~km}$ below the Bhaisalota barrage. The maximum number of fish species (37) was recorded from the spot II and the minimum number (34) from spot I (Tab. 1). During the course of investigation maximum number of species belonged to family Cyprinidae (18) followed by Bagridae (6) and Channidae (5). The family Schilbeidae, Tetraodontidae and Cobitidae represented (3) species each. Notopteridae, Siluridae, Ambassidae and Mastacembelidae represented 2 species each family. Families Sisoridae, Claridae, Heteropneustidae, Belonidae, Belontidae, Nandidae, Gobiidae and Anabantidae were represented by only 1 species each.

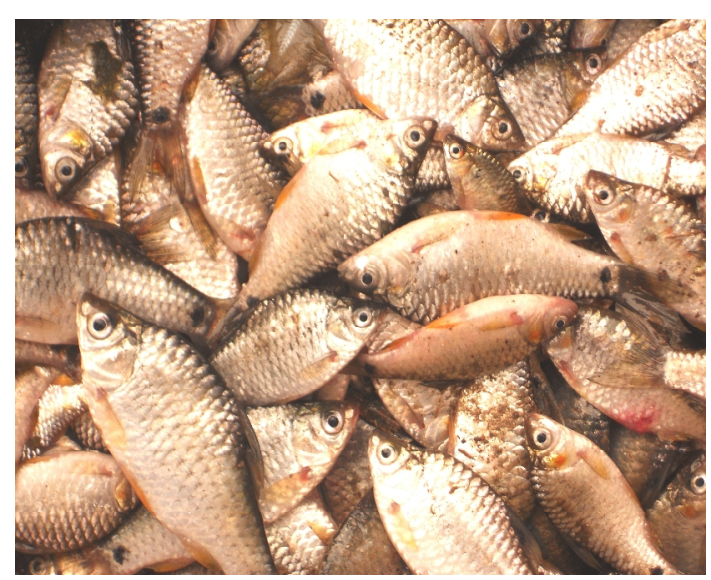

Figure 4. A haul of Puntius sophore

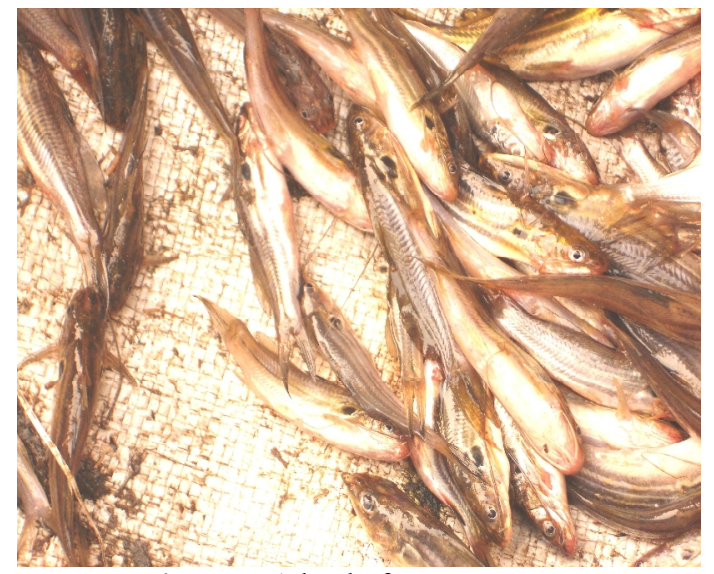

Figure 5. A haul of Mystus tengra 
P.K. Srivastava / Our Nature (2013) 11(1): 76-84

Table 1. Fishes collected from Gandak River, based on Molur and Walker (1998). Taxonomic status adapted from Talwar and Jhingran (1991).

\begin{tabular}{|c|c|c|c|c|c|}
\hline Family/Species & Vernacular name & $\begin{array}{c}\begin{array}{c}\text { Commercial } \\
\text { value }\end{array} \\
\end{array}$ & $\begin{array}{c}\text { Conservation } \\
\text { status } \\
\end{array}$ & Spot I & Spot II \\
\hline \multicolumn{6}{|l|}{ Notopteridae } \\
\hline 1. Notopterus chitala (Hamilton-Buchanan) & Moya & $\mathrm{F}, \mathrm{O}$ & EN & + & + \\
\hline 2. Notopterus notopterus (Pallas) & Patra & $\mathrm{F}, \mathrm{O}$ & LRnt & - & + \\
\hline \multicolumn{6}{|l|}{ Cyprinidae } \\
\hline 3. Aspidoparia morar (Hamilton-Buchanan) & Chippuah & $\mathrm{F}, \mathrm{O}$ & LRnt & + & + \\
\hline 4. Catla catla (Hamilton-Buchanan) & Bhakur & $\mathrm{F}$ & VU & + & - \\
\hline 5. Chela cachius (Hamilton-Buchanan) & Chalhawa & $\mathrm{F}, \mathrm{O}$ & NE & - & + \\
\hline 6. Chela laubuca (Hamilton-Buchanan) & Chalhwa & $\mathrm{F}, \mathrm{O}$ & LRlc & + & + \\
\hline 7. Cirhhinnus mrigala (Hamilton-Buchanan) & Nain & $\mathrm{F}$ & LRnt & - & + \\
\hline 8. Cirhhinus rebe (Hamilton-Buchanan) & Rewa & $\mathrm{F}$ & VU & - & + \\
\hline 9. Cyprinus carpio (Linnaeus) & China rahu & $\mathrm{F}$ & $\mathrm{NE}$ & + & + \\
\hline 10.Labeo bata (Hamilton-Buchanan) & Bata & $\mathrm{F}, \mathrm{O}$ & LRnt & + & - \\
\hline 11.Labeo boga (Hamilton-Buchanan) & Bhagan & $\mathrm{F}, \mathrm{O}$ & LRnt & & \\
\hline 12.Labeo calbasu (Hamilton-Buchanan) & Karaunchar & $\mathrm{F}, \mathrm{O}$ & LRnt & + & + \\
\hline 13.Labeo gonius (Hamilton-Buchanan) & Kursha & $\mathrm{F}$ & LRnt & + & + \\
\hline 14.Labeo rohita (Hamilton-Buchanan) & Rohu & $\mathrm{F}$ & LRnt & - & + \\
\hline 15. Osteobrama cotio (Hamilton-Buchanan) & Gardi & $\mathrm{F}, \mathrm{O}$ & LRnt & + & + \\
\hline 16.Puntius chola (Hamilton-Buchanan) & Sidhari & $\mathrm{F}, \mathrm{O}$ & VU & & \\
\hline 17.Puntius conconius (Hamilton-Buchanan) & Sidhari & $\mathrm{F}, \mathrm{O}$ & VU & & \\
\hline 18.Puntius sarana (Hamilton-Buchanan) & Sidhari & $\mathrm{F}, \mathrm{O}$ & VU & & \\
\hline 19.Puntius sophore (Hamilton-Buchanan) & Sidhari & $\mathrm{F}, \mathrm{O}$ & LRnt & + & - \\
\hline 20.Puntius ticto (Hamilton-Buchanan) & Sidhari & $\mathrm{F}, \mathrm{O}$ & LRnt & + & - \\
\hline \multicolumn{6}{|l|}{ Cobitidae } \\
\hline 21.Botia dario (Hamilton-Buchanan) & Baggha & $\mathrm{F}, \mathrm{O}$ & LRnt & + & + \\
\hline 22.Botia lohachata (Chaudhuri) & & $\mathrm{F}, \mathrm{O}$ & EN & & \\
\hline 23.Lepidocephalus guntea & Nakati & $\mathrm{F}, \mathrm{O}$ & $\mathrm{NE}$ & - & + \\
\hline \multicolumn{6}{|l|}{ Bagridae } \\
\hline 24.Mystus bleekeri (Hamilton-Buchanan) & Tengara & $\mathrm{F}, \mathrm{O}$ & VU & - & + \\
\hline 25.Mystus cavasius (Hamilton-Buchanan) & Sutahawa Tengara & $\mathrm{F}, \mathrm{O}$ & LRnt & + & - \\
\hline 26.Mystus tengara (Hamilton-Buchanan) & Tengara & $\mathrm{F}, \mathrm{O}$ & LRlc & + & - \\
\hline 27.Mystus vittatus (Bloch) & Tengara & $\mathrm{F}, \mathrm{O}$ & VU & + & + \\
\hline 28.Sperata aor (Hamilton-Buchanan) & Dariai Tengara & $\mathrm{F}$ & LRlc & + & + \\
\hline 29.Sperata seenghala (Sykes) & Tengra & $\mathrm{F}$ & LRlc & - & + \\
\hline \multicolumn{6}{|l|}{ Siluridae } \\
\hline 30.Ompok bimaculatus (Bloch) & Jalkapoor & $\mathrm{F}, \mathrm{O}$ & EN & + & + \\
\hline 31.Wallago attu (Schneider) & Barari & $\mathrm{F}, \mathrm{O}$ & LRnt & - & + \\
\hline \multicolumn{6}{|l|}{ Schilbeidae } \\
\hline 32.Aila coila (Hamilton-Buchanan) & Patasi & $\mathrm{F}, \mathrm{O}$ & VU & - & + \\
\hline 33.Clupisoma garua (Hamilton-Buchanan) & Baikari & $\mathrm{F}, \mathrm{O}$ & VU & - & + \\
\hline $\begin{array}{l}\text { 34.Eutropiichthys vacha (Hamilton- } \\
\text { Buchanan) }\end{array}$ & Banjhoo & $\mathrm{F}, \mathrm{O}$ & EN & - & + \\
\hline \multicolumn{6}{|l|}{ Sisoridae } \\
\hline 35.Bagarius bagarius (Hamilton-Buchanan) & Gonchita & $\mathrm{F}$ & VU & + & + \\
\hline \multicolumn{6}{|l|}{ Claridae } \\
\hline 36. Clarias batrachus (Linnaeus) & Mangur & $\mathrm{F}, \mathrm{O}$ & VU & - & + \\
\hline $\begin{array}{l}\text { Heteropneustidae } \\
\text { 37.Heteropneustes fossilis (Bloch) }\end{array}$ & Singhi & $\mathrm{F}, \mathrm{O}$ & VU & + & + \\
\hline
\end{tabular}


P.K. Srivastava / Our Nature (2013) 11(1): 76-84

\begin{tabular}{|c|c|c|c|c|c|}
\hline $\begin{array}{l}\text { 38. Xenentodon cancila (Hamilton- } \\
\text { Buchanan) }\end{array}$ & Kauwa & $\mathrm{F}, \mathrm{O}$ & LRnt & + & + \\
\hline \multicolumn{6}{|l|}{ Ambassidae } \\
\hline 39. Chanda nama (Hamilton-Buchanan) & Chanda & $\mathrm{F}, \mathrm{O}$ & LRlc & - & + \\
\hline 40.Parambassis lala (Hamilton) & Chanari & $\mathrm{F}, \mathrm{O}$ & NE & + & + \\
\hline \multicolumn{6}{|l|}{ Nandidae } \\
\hline 41.Nandus nandus (Hamilton-Buchanan) & Dhalae & $\mathrm{F}, \mathrm{O}$ & LRnt & + & + \\
\hline \multicolumn{6}{|l|}{ Gobiidae } \\
\hline 42.Glossogobius giuris (Hamilton-Buchanan) & Bulla & $\mathrm{F}, \mathrm{O}$ & LRnt & + & - \\
\hline \multicolumn{6}{|l|}{ Anabantidae } \\
\hline 43.Anabas testudineus (Bloch) & Sumha & $\mathrm{F}, \mathrm{O}$ & VU & + & + \\
\hline \multicolumn{6}{|l|}{ Belontidae } \\
\hline 44. Colisa faciatus (Schneider) & Khosti & $\mathrm{F}, \mathrm{O}$ & LRnt & + & - \\
\hline \multicolumn{6}{|l|}{ Channidae } \\
\hline 45.Channa gachua (Hamilton) & Changa & $\mathrm{F}$ & $\mathrm{NE}$ & + & + \\
\hline 46. Channa marulius (Hamilton-Buchanan) & Saur & $\mathrm{F}$ & LRnt & + & - \\
\hline 47.Channa striata (Bloch) & Soura & $\mathrm{F}$ & LRnt & + & + \\
\hline 48. Channa orientalis (Bloch and Schneider) & Changa & $\mathrm{F}, \mathrm{O}$ & VU & + & + \\
\hline 49.Channa punctatus (Bloch) & Girae & $\mathrm{F}$ & LRnt & + & - \\
\hline \multicolumn{6}{|l|}{ Mastacembelidae } \\
\hline 50.Mastacembelus armatus (Lacepede) & Baam & $\mathrm{F}, \mathrm{O}$ & LRlc & + & + \\
\hline 51.Macrognathus pancalus (Hamilton-Buch.) & Patya (Nakati) & $\mathrm{F}, \mathrm{O}$ & NE & + & - \\
\hline \multicolumn{6}{|l|}{ Tetraodontidae } \\
\hline 52.Tetradon cutcutia (Hamilton-Buchanan) & Galphulani & $\mathrm{F}, \mathrm{O}$ & LRnt & + & - \\
\hline 53.Tetradon fluviatilis (Hamilton) & Beng macharia & $\mathrm{F}, \mathrm{O}$ & LRnt & + & + \\
\hline 54.Monopterus cuchia (Hamilton-Buchanan) & Anhaya Baam & $\mathrm{F}, \mathrm{O}$ & LRnt & - & + \\
\hline
\end{tabular}

Cyprinidae contributed highest of 33\% fish species (Fig. 3), among which, Cabdio morar (Chepua) and Puntius sp. (Sidhari) were the most abundant forms (Fig. 4), Labeo rohita (Rohu), Catla catla (Bhakur) and Cirhhinus mrigala (Nain) were not found in good number but Labeo bata, Labeo boga and Labeo calbasu occured in good quantity. Mystus sp. was recorded in abundance with the occurrence all the year round (Fig. 5).

David (1963) recorded availability of Hilsa ilisha from close to Bettiah but in the present study, it was not recorded in this stretch. Exotic fishes like Cyprinus carpio was also recorded from the river but their number of catch was negligible. It is a sad commentary that the Indian Major Carps have declined sharply in the last one decade while forage and catfishes are increasing drastically in the river. Fishers catch on an average about 5-6 $\mathrm{kg}$ of fish daily dominated by miscellaneous and cat fishes.

According to fishers assumption, the fish catch of the river has declined during last two decades, may be due to climate fluctuation, indiscriminate fishing of brood stock in the spawning ground and use of smaller mesh size of fishing net.

Apart from Indian Major Carps (Labeo rohita, Catla catla, Cirrhinus mrigala), Chitala chitala, Notopterus notopterus, Ompok pabda, O. bimaculatus, Labeo bata, L. calbasu, Cirrhinus reba, Channa marulius, Bagarius bagarius, and Clupisoma garua were the other commercially 
P.K. Srivastava / Our Nature (2013) 11(1): 76-84
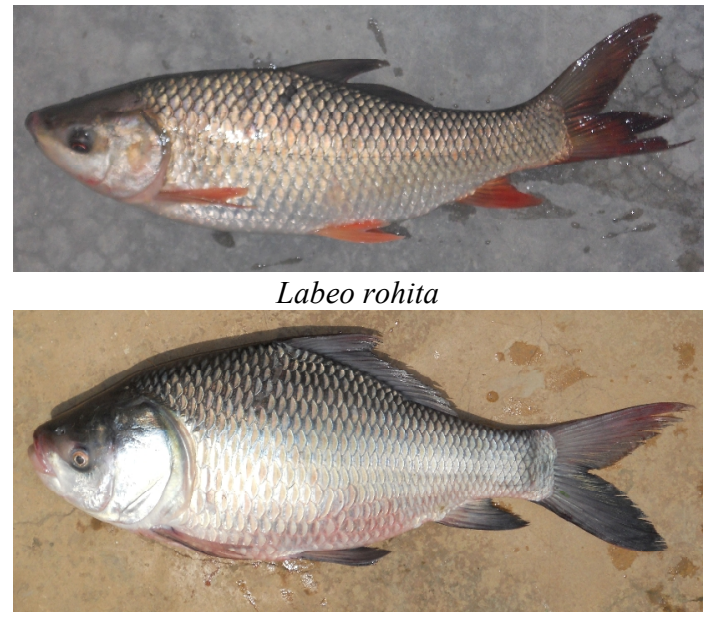

Catla catla

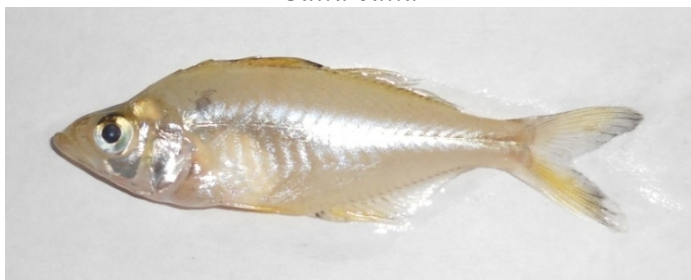

Chanda nama

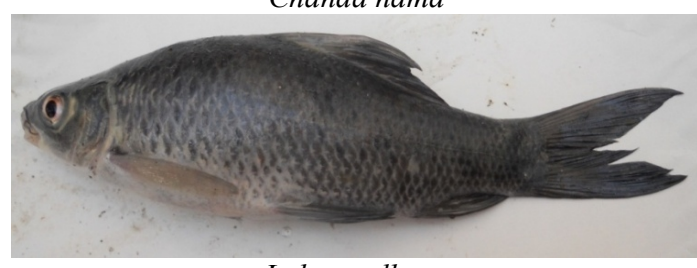

Labeo calbasu

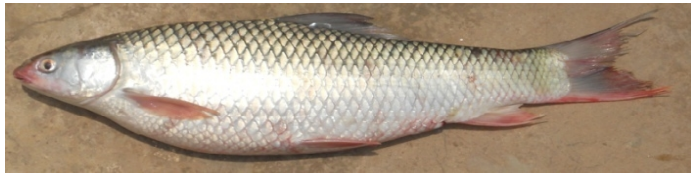

Cirhinnus mrigala

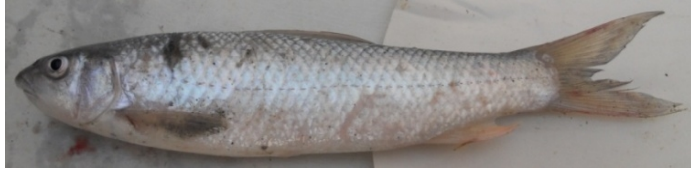

Cirrhinus reba

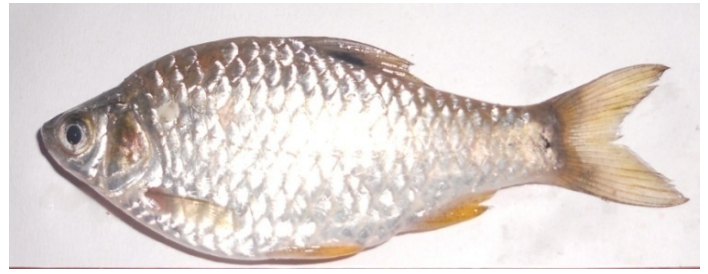

Puntius sophore

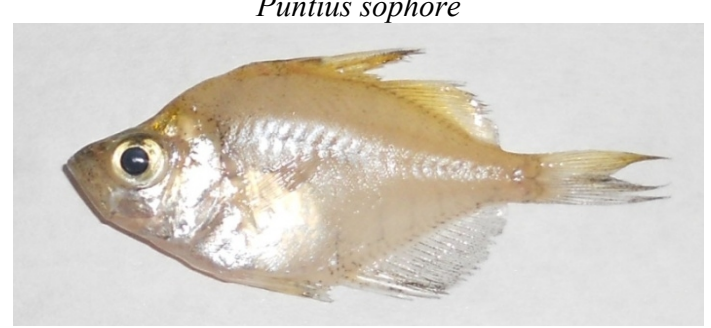

Parambassis ranga

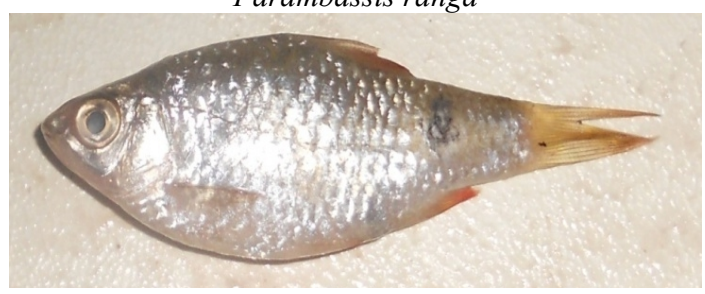

Puntius conchonius

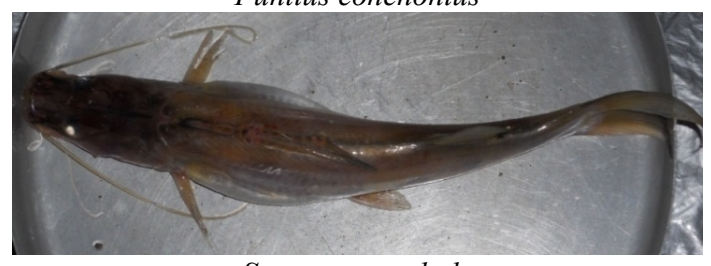

Sperata seenghala

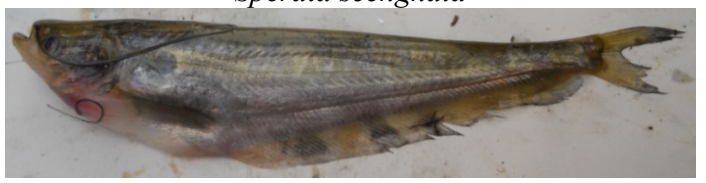

Ompok bimaculatus

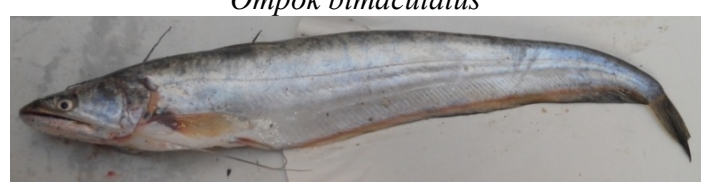

Wallago attu

Plate 1. Important fishes of Gandak River. 
P.K. Srivastava / Our Nature (2013) 11(1): 76-84

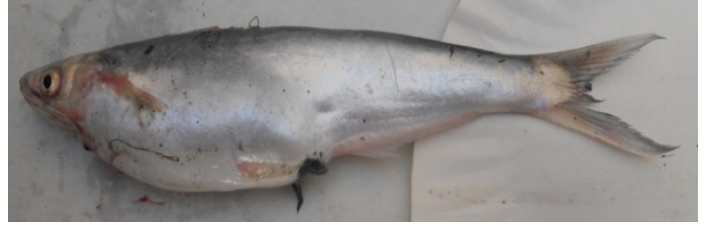

Eutropiichthys vacha

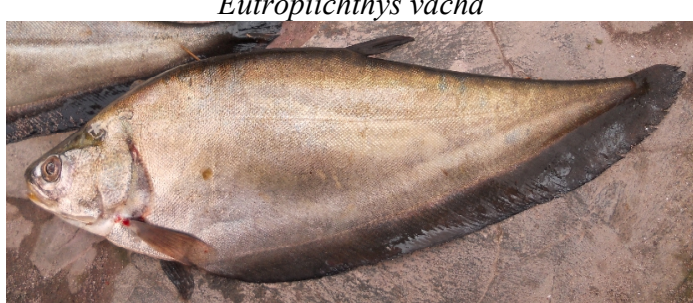

Notopterus notopterus

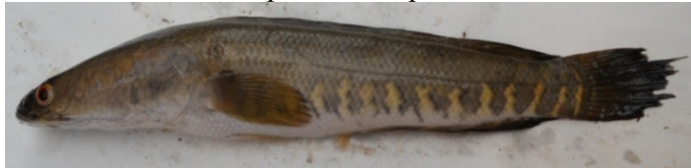

Channa striatus

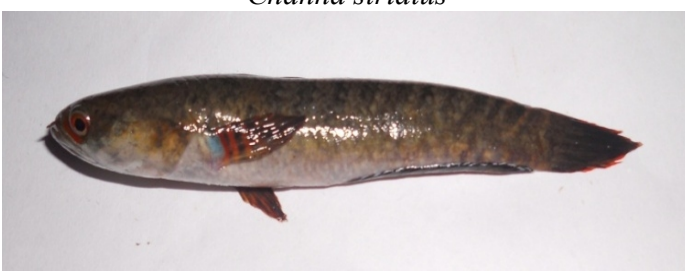

Channa orientalis

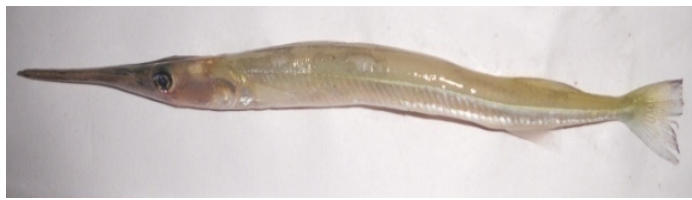

Xenentodon cancila

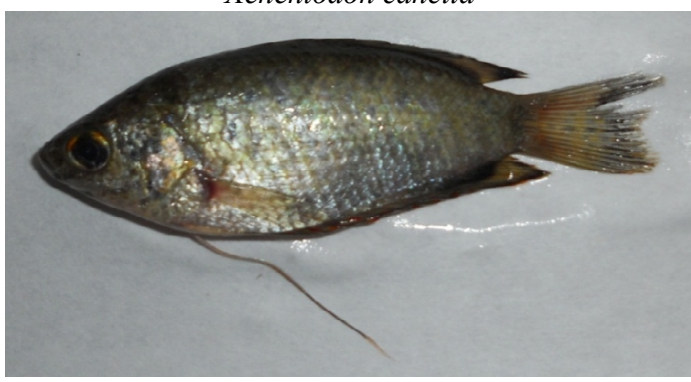

Colisa faciata

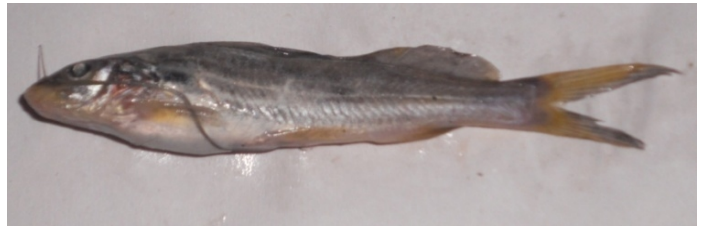

Mystus bleekeri

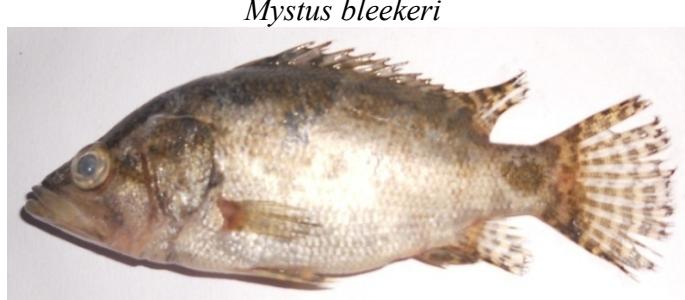

Nandus nandus

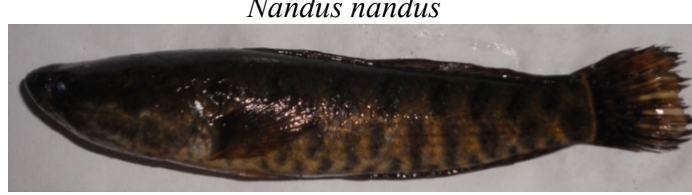

Channa punctatus

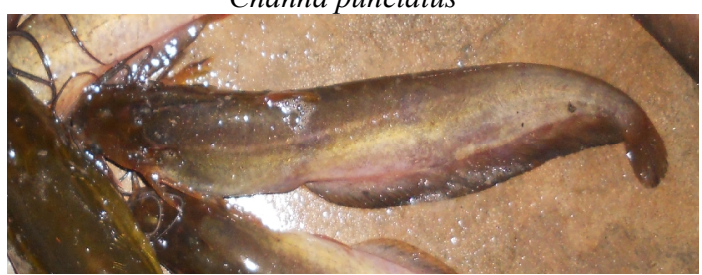

Heteropneustes fossilis

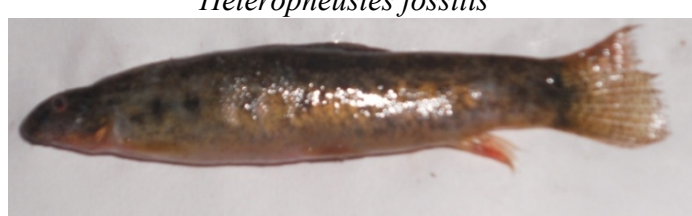

Lepidocephalus guntea

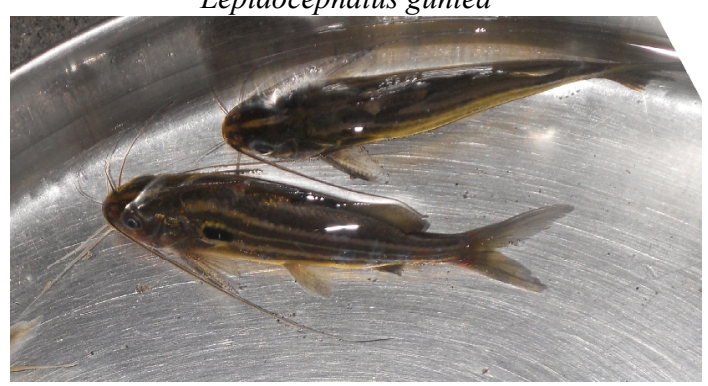

Mystus tengra

Plate 2. Important fishes of Gandak River. 


\section{P.K. Srivastava / Our Nature (2013) 11(1): 76-84}

important species of the collection (Pls 1 and 2).

A good number of ornamental fishes were also recorded during the present investigation. Due to lack of proper knowledge of the value and marketing of ornamental fishes among the fishers, these are sold at a very low price. Most of the fish catch is sold by fishers on spot to brokers and brokers finally sale it in local fish markets at higher rates.

\section{Conclusion and recommendations}

- Indiscriminate fishing has been observed during the entire study period, which has resulted in tremendous decrease of major carps.

- Fish sanctuary needs to be established to preserve fish stocks and indigenous brood fishes.

- Fishery regulation should be strictly followed to protect fish species and enhance the fish production especially Indian major carps. Indian major carps are high priced fishes, but their stocks are declining. To conserve the Indian major carp less than 2 $\mathrm{cm}$ mesh size nets should be totally banned specially during the breeding season.

- Awareness campaigns should be conducted among the fishers with regard to the value of ornamental fish species and obtain higher price.

- As reported by various fishermen the decline in fish catch was due to indiscriminate fishing, usage of fine nets, siltation, changing land use pattern and flood. This has resulted and forced many of them to migrate and change their profession.

Thus, awareness programmes among fishers, strict ban on illegal monsoon fishing and usage of small mesh nets besides the protection of breeding grounds of com- mercially important fish species are some of the management measures, which would protect and conserve the precious fish diversity of the system.

\section{Acknowledgements}

The author is highly grateful to Dr. N.P. Shrivastava, Rtd. Principal Scientist and Joint Secretary, Inland Fisheries Society of India, Central Inland Fisheries Research Institute, Barrackpore, Kolkata for critically going through the manuscript and his valuable suggestions.

\section{References}

Bhat, A. 2000. Book Reviews. Current Science 79(3): 382-383.

Cowx, I.G. 1998. Aquatic resource management planning for resolution of fisheries management issues. In Recreational fisheries: Social, economic and management aspects (Eds. P. Hickley and $\mathrm{H}$ Tompkins). Fishing News Books, Blackwell Science, Oxford. pp. 97-105.

Das, M.K., A.P. Sharma, R.K. Tyagi, P.K. Saha, V. Pathak, V.R. Suresh, D.K. De, S.K. Paul, P. Sett, M. Chakraborty and K. Mondal 2010. Fishes of river Ganga - A field identification manual. Central Inland Fisheries Research Institute, Bulletin Number 165.93p.

David, A. 1963. Report on fisheries survey of the river Gandak (North Bihar). Survey Report No. 1. Central Inland Fisheries Research Institute, Barrackpore, India.

Day, F. 1978. The fishes of India being a natural history of the fishes known to inhabit the seas and freshwater of India, Burma and Ceylon, Vol. I and II, William Dawson and Sons Ltd., London. 778p.

Jayaram, K.C. 1999. The freshwater fishes of the Indian region. Narendra Publishing House, Delhi. $571 \mathrm{p}$.

Jhingran, V.G. 1975. Fish and fisheries of India. Hindustan Publishing Corporation, India. 954p.

Lakra, W.S., K.K. Lal and V. Mohindra 2006. Genetic characterization and upgradation of fish species for enhanced aquaculture production and biodiversity conservation. Fishing Chimes 26(1): 256-258.

Lakra, W.S., U.K. Sarkar, A. Gopalakrishnan and A. 


\section{P.K. Srivastava / Our Nature (2013) 11(1): 76-84}

Kathirvelpandian 2010. Threatened freshwater fishes of India. National Bureau of Fish Genetic Resources, Indian Council of Agricultural Research, India. 25p.

Linderberg, G.V. 1976. Fishes of the world. A key to families and checklist. John Wiley and Sons, New York. 545p.

Menon, A.G.K. 1974. A check list of fishes of Himalayan and the Indo-Gangetic plains. Special publication IFSI. 1: 1-136.

Mittermeier, R.A., P.R. Gil and C.G. Mittermeier 1997. Megadiversity Earth's biologically wealthiest Nation. CEMEX. 501p.
Molur, S. and S. Walker 1998. Report of the workshop on Conservation Assessment and Management Plan for Freshwater fishes of India. Zoo Outreach Organisation, Conservation Breeding Specialist Group, Coimbatore, India. 156p.

Srivastava, G.J. 1986. Fishes of Eastern Uttar Pradesh. Vishwavidyalaya Prakashan, Varanasi. 163p.

Talwar, P.K. and A.G. Jhingran 1991. Inland fishes of India and adjacent countries, Vol I and II. Oxford and IBH Publishing Co. Pvt. Ltd., New Delhi. $1158 \mathrm{p}$. 